\title{
Flexible Micro Finance Program: Effectiveness and Efficiency to Reach the Extreme Poor
}

\author{
Meherun AHMED*, Baqui KHALILY*,Abdul KHALEQUE ${ }^{* * *}$,S. Nafisa NAWAL ${ }^{* * * *}$
}

Received: January 13, 2017 Revised: September 3, 2017 Accepted: September 15, 2017

\begin{abstract}
Following widespread criticisms of the conventional MFI framework, Plan Bangladesh, an INGO devised a flexible credit scheme characterized by door to door collection of deposits and loan repayments on a day to day basis. The scheme departs from the joint liability mechanism practiced by traditional MFIs in an effort to disburse services to the ultra poor, who are often excluded by community screening mechanisms as well as service providers. This paper aims to test the viability of a flexible scheme offering products developed through participatory market research targeted at individuals. We find the scheme to be highly effective, enhancing income of ultra poor households as well as providing adequate leverage for asset accumulation.
\end{abstract}

Keywords: Flexible Credit, Saving, Ultra poor, Bangladesh, Microfinance Institutes, PLAN International

JEL Code Classification: C21, D14, G23, L31, 011

UDC: 336.581 .2

DOI: https://doi.org/10.17015/ejbe.2017.020.04.

\footnotetext{
* Corresponding author. Associate Professor, Asian University for Women, Chittagong, Bangladesh.

E-mail: meherun.ahmed@auw.edu.bd

** Professor, University of Dhaka, Bangladesh. E-mail:bkhalily51@gmail.com

${ }^{* * *}$ Assistant Professor, University of Dhaka, Bangladesh. E-mail: khaleque_du@yahoo.com

**** Senior Research Assistant, James P Grant School of Public Health, BRAC University, Dhaka, Bangladesh. E-mail: snafisanawal@gmail.com

Copyright @ , 2017 Ala-Too International University.
} 


\section{Introduction}

Poverty alleviation interventions can be fundamentally defined as functions of financial capital and human capital development. While it is essential to ensure simultaneous development of both, developing financial capital ensures subsequent positive impact on the growth of human capital, income, wealth accumulation and socio-economic wellbeing of impoverished communities. Simple financial interventions such as microfinance that ensure access to credit for the poor have proven to be a boon in the context of countries such as Bangladesh. Home to a staggering 153 million (World Bank, 2011) of which 25\% are below the poverty line (Bangladesh Bureau of Statistics, 2010), Bangladesh is often lauded as the cradle of microfinance with programs characterized by enviable outreach and variety of institutional arrangements. Approximately USD 3.564 billion has been disbursed to 19.98 million beneficiaries by micro finance institutes (MFIs) in 2014 (Microcredit Regulatory Authority, 2015); lenders include five nationalized commercial banks, two development finance institutions, Grameen Bank and Palli Karma Sahayak Foundation as public-private institutional hybrids, eighteen credit unions and 681 licensed non-governmental organizations (NGOs) (Microcredit Regulatory Authority, 2016).

Despite the preeminence of MFIs in the country, only $24.5 \%$ of their services are disbursed to the ultra poor (Rahman, 1998). While $12.4 \%$ of the country's population suffer from extreme poverty (Bangladesh Bureau of Statistics, 2010) three-fourth of the ultra poor report never receiving credit services from NGOs (Matin \& Hulme, 2003). The ultra poor remains excluded from availing services offered by MFIs (Rahman \& Razzaque, 2000), primarily due to the enforcement of joint liability lending policies. Though non financial group collateral promotes monitoring and ensures repayment (Ghatak \& Timothy, 1999), the process almost always forces members to screen out the poorest of the poor - those with the least ability to repay. As MFIs thrive to attain long run sustainability, designing innovative products that cater to the needs of the ultra poor remains a daunting challenge. In recent times, savings from beneficiaries have become increasingly important to ensure the sustainability of MFIs.

Plan Bangladesh, an INGO, recently devised an innovative financial intervention that offered simplified savings and credit facilities across Dinajpur and Nilphamari regions. Unlike traditional microfinance practices, this intervention, referred to as Microfinance for the Extreme Poor (MEP) Program, is characterized by door to door delivery of flexible credit and savings products. Using a participatory product development process, each beneficiary is offered a different saving or credit scheme where they can deposit or repay loans on a day to day basis. Minimum or maximum amounts are not applicable for deposits. Loans allow for flexible installments and a $4 \%$ interest rebate on early repayment. Effective nominal interest rates revolve around $23 \%$. All collections are made by community workers residing in target villages; they are hired by implementing partners Come to Save 
(CTS) and People's Oriented Program Implementation (POPI), who oversee the management and administration of the MEP Program.

This paper aims to evaluate the impact of this flexible credit scheme and determine its efficiency. We seek to answer whether flexible credit facilities targeted at individuals may be more effective compared to the joint liability process practiced by traditional MFIs.

\section{Literature Review}

The impact of micro loans on poverty alleviation and the importance of savings have been revisited in literature time and again. Advocates of microfinance have celebrated the success of the traditional model introduced by Grameen Bank (Yunus, 2004), that has been successfully replicated in distinctive environments in the years to come. Case in point, the traditional MFI model has been adapted to countries as far away as Bosnia-Herzegovina, where microfinance has rivaled conventional banking systems despite instability of government systems (Hamad \& Duman, 2013). Despite adaptations to diverse socio-economic environments, the joint liability mechanism remains a characteristic feature of MFIs worldwide. This mechanism is believed to essential as a monitoring process, ensuring the realization of outstanding loans and feasibility of programs (Ghatak \& Timothy, 1999). However, MFIs operated by NGOs are often accused of leaving out the poorest of the poor, emphasizing on the need to formulate more inclusive programs that integrate the most deprived communities (Ahmed, 2003). Besides, small enterprise growth rates were found to be stunted in the presence of the joint liability mechanism, specifically when fixed installments on loans were applicable (Field, Pande, Papp, \& Rigol, 2013). Reliance on returns from outstanding loans often leads MFIs to extract higher interest rates, therefore causing more harm than good on beneficiaries (Sriram \& Parhi, 2006). Households often find themselves struggling with unmanageable debt, which in turn leads to deterioration of their societal standing and community ties (Guérin, 2014). Lack of demand driven products has been reported as the prime reason for beneficiaries gradually dropping out of MFI schemes (Meyer, 2002).

Following the criticisms faced by this noble enterprise, several authors have argued in favor of innovation and newer practices to revamp MFIs and realize the latent potential of micro credit (Basu \& Srivastava, 2005). Development of human capital and prospects of higher income in future are contingent on savings, though savings may be prone to institutional effects (Ssewamala \& Sherraden, 2004). MFIs enjoy the advantage of familiarity with a huge untapped market for savings, exploitation of which could lead to greater sustainability in the long run (Sriram \& Parhi, 2006). Flexible savings for the ultra poor and matched savings accounts inspired by women's saving habits have the potential to reach the greater community through MFIs (Vonderlac \& Schreine, 2002). MFIs led by savings are also expected to be 
resilient in the face of national and global financial crises (Seibel, Rachmadi, \& Kusumayakti, 2010).

However, implementation of flexible mechanisms is inevitable to accommodate innovative products and services within the MFI framework. Paradoxical styles of product development, such as the participatory product development mechanism adopted by Plan, are found to enhance performance while uncertainties lead to moderation in management-performance relationships (Lewis, Welsh, Dehler, \& Green, 2002). In fact, participatory market research has proven to be successful in a wide range of contexts, as in the case of Mixtec craftswomen of Mexico (Giron, Hernandez, \& Castaneda, 2004). A GIS analysis aimed at understanding spatial accessibility to microfinance concluded that borrowing increased significantly when MFIs were more accessible (Khan \& Rabbani, 2015). Based on this argument, it may be claimed that door to door collection will encourage beneficiaries to save and repay loans on time, hence increasing the utilization of micro credit in vulnerable communities. Considering that the aspects incorporated in the MEP intervention are supported by literature, we observe that the program is viable in the context of Bangladesh.

\section{Study Design}

Difference in Difference, Sample Mean Comparison and Randomized Controlled Trial are among the most popular techniques used in impact evaluation or assessment. To assess the impact of the Plan MEP Program, we adopt a Randomized Controlled Trial Process (RCT). RCTs are often argued to be powerful methods of impact assessment, enabling policy makers to take more informed decisions regarding resource allocation for interventions that change lives for the better (Olofsgard, 2014). We further conduct sample Mean Comparisons within the treatment and control groups. The results are reported in Annex A.

As implementation partners of Plan Bangladesh, CTS and POPI administered the MEP scheme across regions with rampant poverty ${ }^{1}$. CTS has served an aggregate of 21170 beneficiaries through a network of 10 branches across 53 villages in Chiribandhar and Khansama Upazilas of Dinajpur district. With a network of 7 branches across 38 villages in Hatibandha Upazila of Lalmonirhat and Jaldhaka Upazila of Nilphamari, POPI has mobilized 8846 beneficiaries altogether. Considering the extent of operations by each implementing partner in treatment areas, 4 branches from POPI and 6 branches from CTS were randomly selected. 60 households catered by each of these 10 branches were then randomly selected, adding up to a total of 600 sample households under the treatment group. These 600 households were then categorized into groups A, B, C, D and E based on their income levels; $A$ being relatively affluent and $E$ being the most disadvantaged.

\footnotetext{
${ }^{1}$ Dinajpur, Nilphamari and Rangpur are among the historically impoverished regions of Bangladesh, alike most of the northwestern parts (Bangladesh Bureau of Statistics, 2006).
} 
The control group was particularly difficult to identify, owing to the wide outreach of MFIs in the country as well as spillover effects. Nevertheless, 150 households from 8 villages in Mithapukur Upazila of Rangpur were identified as the control group, where traditional MFIs have been operating but schemes similar to MEP were not. InM and Plan Bangladesh were careful to ascertain that household characteristics of treatment and control areas were homogenous, MEP being the only differentiating factor between sample units.

Under the supervision of Plan and InM, a team of 15 trained enumerators collected data over a period of one week in May 2010 using paper based surveys. The following information were extracted from sample households: demographic information, socioeconomic status, sources of income, asset information, savings, financial liability, social safety net programs, food and non food expenditure, migration and remittance, disasters and remedies. InM and Plan conducted frequent audits on randomly selected surveys to monitor and maintain the quality of data.

\section{Methodology}

To address the absence of panel data, we compare means between treatment and control sample units. If outcomes of treatment households are higher than those for the control households, we postulate the program to have an impact, the difference between two outcomes being the magnitude of impact. Since we use a cross-sectional data set, ceteris paribus, the program impact is defined as

$$
D=\overline{Y_{p}}-\overline{Y_{n p}}
$$

where $\mathrm{D}$ is difference between outcomes of participants and non-participants. $\overline{Y_{p}}$ and $\overline{Y_{n p}}$ refer to mean outcome of participants and non-participants, respectively. We conduct t-tests to evaluate mean difference of sample households before and after association with MEP program.

In line with the vast body of microeconomic research, we first adopt a basic OLS breakdown of the variables of interest. In a standard cross-section regression model with $\mathrm{N}$ observations on a scalar dependent variable and several regressors, the data are specified as $(\boldsymbol{y}, \boldsymbol{X})$, where $\boldsymbol{y}$ denotes observations on the independent variable and $\boldsymbol{X}$ denotes a matrix of explanatory variables. In matrix notation the observations are stacked by row to yield:

$$
\boldsymbol{y}=\boldsymbol{X} \boldsymbol{\beta}+\epsilon
$$

Here, $\boldsymbol{y}$ is a $N \times 1$ vector of dependent or endogenous variables whose variations we wish to study in terms of variation in exogenous or explanatory variables; $\boldsymbol{X}$ is a $N \times K$ regression matrix, and $\epsilon$ is a $N \times 1$ vector of disturbance terms.

Our model is specified as follows: 


$$
\begin{aligned}
y=\alpha+\beta_{1} \text { Headed } & \text { dby }+\beta_{2} \text { Age of household head } \\
& +\beta_{3} \text { percent of member educated }+\beta_{4} \text { Family size } \\
& +\beta_{5} \text { Employment in agri.or non }- \text { agri }+\beta_{6} \text { Total land } \\
& +\beta_{7} \text { Have electricity }+\beta_{8} \text { Migrate }+\beta_{9} \text { Safety net support } \\
& +\beta_{10} \text { Participation }+\beta_{10 i} \text { A set of village dummies }+u
\end{aligned}
$$

Four major specifications are being used to see the changes in outcome of interests. The basic model includes the fundamental characteristics of household head, households and the dummy for the program, gradually adding other explanatory variables in the following regressions. Village level specific effects are introduced in the last model to address unobserved attributes affecting household behavior and their subsequent impact on income.

Considering the limitations of a linear model, we adopt a Probit model analysis to further understand the impact of MEP on the propensity to save. For binary outcome data the dependent variable $\boldsymbol{y}$ takes one of two values. We let:

$$
\boldsymbol{y}=\left[\begin{array}{lr}
1 & \text { with probability } p \\
0 & \text { with probability }(1-p)
\end{array}\right.
$$

A regression model is formed by considering the probability $\mathrm{p}$ to depend on a regressor vector $\boldsymbol{X}$ and a $K \times 1$ parameter vector $\boldsymbol{\beta}$. The commonly used models are of single-index form with conditional probability given by:

$$
p_{i}=\operatorname{Pr}\left[y_{i}=1 \mid X\right]=F\left(x_{i}^{\prime} \beta\right)
$$

Here $F($.$) is a specified function. To ensure that 0 \leq p \leq 1$ it is natural to specify $F($. $)$ to be a cumulative distribution function. The Probit model specifies the conditional probability:

$$
p=\Phi\left(x^{\prime} \beta\right)=\int_{-\infty}^{x^{\prime} \beta} \phi(z) d z
$$

Here $\Phi($.$) is the standard normal cdf (cumulative density function), with$ derivative $\phi(z)=(1 / \sqrt{2 \pi}) \exp \left(-\frac{z^{2}}{2}\right)$, which is the standard normal density function.

The Probit maximum likelihood estimation (MLE) first - order conditions are that

$$
\sum_{i=1}^{N} w_{i}\left(y_{i}-\Phi\left(x_{i}^{\prime} \beta\right)\right) x_{i}=0
$$

Here, $w_{i}$ is the weight which is defined as $w_{i}=\phi\left(x_{i}^{\prime} \beta\right) /\left[\Phi\left(x_{i}^{\prime} \beta\right)-\left(1-\Phi\left(x_{i}^{\prime} \beta\right)\right]\right.$ varies across observations. The Probit model marginal effects are $\frac{\partial p_{i}}{\partial x_{i j}}=$ $\phi\left(x_{i}^{\prime} \beta\right) \beta_{j}=\phi\left(\Phi^{-1}\left(p_{i}\right)\right) \beta_{j}$, where $_{i}=\Phi\left(x_{i}^{\prime} \beta\right)$. 
In our analysis, we have used Probit for latent variables ${ }^{2}$. In the index function formulation interest lies in explaining an underlying unobserved continuous random variable $y^{*}$, but all we observe is the binary variable $y$, which takes value 1 or 0 according to whether or not $y^{*}$ crosses a threshold.

We let $y^{*}$ be a latent or unobserved variable such as the desire to save or propensity to save if the saving function is being modeled. The natural regression model for $y^{*}$ is the index function model:

$$
y^{*}=X^{\prime} \beta+u
$$

However, this model can't be estimated as $y^{*}$ is not observed. Instead, we observe:

$$
y=\left\{\begin{array}{l}
1 \text { if } y^{*}>0 \\
0 \text { if } y^{*} \leq 0
\end{array}\right.
$$

Here the threshold of zero is a normalization explained in the following.

$$
\begin{aligned}
\operatorname{Pr}[y=1 \mid X]= & \operatorname{Pr}\left[y^{*}>0\right] \\
& =\operatorname{Pr}\left[X^{\prime} \beta+u>0\right] \\
& =\operatorname{Pr}\left[-u>X^{\prime} \beta\right] \\
& =F\left(X^{\prime} \beta\right)
\end{aligned}
$$

Here $F$ is the cdf of $(-u)$, which equals the cdf of $u$ in the usual case of density symmetric about zero. The Probit model arises if the error $u$ is standard normal distribution. We further employ a Tobit regression to ascertain the extent to which determinants of savings influence savings, by using left bound truncation ${ }^{3}$.

\section{Findings}

As per the study design, the 600 treatment households were classified into five different income groups; $A$ being the relatively affluent ones and $E$ being the most deprived. $92 \%$ of the MEP beneficiaries belonged to the lower income groups $C, D$ and $E$ while $8 \%$ of them belonged to the higher income groups $A$ and $B$. We find that CTS had better targeting towards beneficiaries from the lower income groups compared to POPI, based on statistically significant mean comparison.

As observed in the summary statistics, mean annual food expenditure does not vary substantially across the sample households. However mean savings differ widely, which could be attributed to the difference in mean annual income. Ownership of assets also varies widely between the samples. We conduct a series

\footnotetext{
${ }^{2}$ A latent variable is a variable that is incompletely observed. Latent variables can be introduced into binary outcome models in two different ways. In the first the latent variable is an index of an unobserved propensity for the event of interest to occur. In the second the latent variable is the difference in utility that occurs if the event of interest occurs, which presumes that the binary outcome is a result of individual choice.

${ }^{3}$ Lower bound truncation was used to censor the observations which did not save despite having access.
} 
Meherun AHMED, Baqui KHALILY, Abdul KHALEQUE \& Syeda Nafisa NAWAL

of mean comparison tests to compare annual income and annual expenditure before and after association with the MEP program, detailed tables for which have been provided in the annex. Below we report only the statistically significant findings from mean comparisons.

\section{Table 1. Summary Statistics of Sample Households}

\begin{tabular}{clllllll}
\hline $\begin{array}{l}\text { Household } \\
\text { Category }\end{array}$ & $\begin{array}{l}\text { Mean } \\
\text { savings }\end{array}$ & $\begin{array}{l}\text { Mean } \\
\text { annual } \\
\text { income }\end{array}$ & $\begin{array}{l}\text { Mean } \\
\text { annual food } \\
\text { expenditure }\end{array}$ & $\begin{array}{l}\text { Mean annual } \\
\text { non-food }\end{array}$ & $\begin{array}{l}\text { Mean } \\
\text { agricultural } \\
\text { land }\end{array}$ & $\begin{array}{l}\text { Mean } \\
\text { homestead }\end{array}$ & $\begin{array}{l}\text { Mean } \\
\text { livestock }\end{array}$ \\
\hline A & 9393.36 & 125909.10 & 51981.82 & 19463.64 & 306.36 & 15.55 & 6.91 \\
B & 6292.65 & 109675.70 & 50063.51 & 28271.62 & 126.51 & 16.65 & 6.86 \\
C & 6328.27 & 96475.45 & 45704.97 & 10389.91 & 83.61 & 11.09 & 4.63 \\
D & 3484.09 & 65968.38 & 39031.98 & 6798.34 & 22.44 & 5.83 & 3.40 \\
E & 6211.64 & 67485.26 & 39737.84 & 9324.95 & 19.74 & 4.46 & 3.12 \\
Control & 1789.96 & 44056.00 & 35502.31 & 5569.79 & 4.51 & 5.63 & 2.83 \\
\hline
\end{tabular}

Participating households have a higher annual income compared to control households, which is significant at $1 \%$ level of significance.

\section{Table 2. Impact of MEP on current income}

\begin{tabular}{|c|c|c|c|c|}
\hline & Model - 1 & Model - 2 & Model - 3 & Model -4 \\
\hline Log(Income) & Coefficient & Coefficient & Coefficient & Coefficient \\
\hline \multirow[t]{2}{*}{ Gender of household head } & $0.450 * * *$ & $0.485^{* * *}$ & $0.492 * * *$ & $0.447^{* * *}$ \\
\hline & $(0.098)$ & $(0.089)$ & $(0.089)$ & $(0.091)$ \\
\hline \multirow[t]{2}{*}{ Age of household head } & $0.004 * *$ & 0.002 & 0.002 & 0.001 \\
\hline & $(0.002)$ & $(0.002)$ & $(0.002)$ & $(0.002)$ \\
\hline \multirow[t]{2}{*}{ Education level of household head } & $0.043^{* * *}$ & $0.016^{* *}$ & $0.016^{* *}$ & 0.010 \\
\hline & $(0.007)$ & $(0.006)$ & $(0.006)$ & $(0.007)$ \\
\hline \multirow[t]{2}{*}{ Safety net support } & 0.000 & -0.000 & -0.000 & 0.000 \\
\hline & $(0.000)$ & $(0.000)$ & $(0.000)$ & $(0.000)$ \\
\hline \multirow[t]{2}{*}{ Participant $=1$, Control $=0$} & $0.449 * * *$ & $0.335^{* * *}$ & $0.319 * * *$ & $0.597^{* *}$ \\
\hline & $(0.066)$ & $(0.061)$ & $(0.061)$ & $(0.288)$ \\
\hline \multirow[t]{2}{*}{ Employment in agri. $=0$, non-agri. $=1$ ) } & & $0.243 * * *$ & $0.245 * * *$ & $0.214 * * *$ \\
\hline & & $(0.048)$ & $(0.048)$ & $(0.050)$ \\
\hline \multirow[t]{2}{*}{ Total land } & & $0.003 * * *$ & $0.003 * * *$ & $0.003 * * *$ \\
\hline & & $(0.000)$ & $(0.000)$ & $(0.000)$ \\
\hline \multirow[t]{2}{*}{ Is there any electricity in the $\mathrm{HH}$ ? } & & & -0.019 & -0.045 \\
\hline & & & $(0.062)$ & $(0.065)$ \\
\hline \multirow[t]{2}{*}{ Migrate: $Y e s=1$, No $=0$} & & & $0.141^{*}$ & 0.054 \\
\hline & & & $(0.076)$ & $(0.100)$ \\
\hline \multirow[t]{2}{*}{ Constant } & $9.848^{* * *}$ & $9.851^{* * *}$ & $9.853^{* * *}$ & $9.819 * * *$ \\
\hline & $(0.140)$ & $(0.129)$ & $(0.129)$ & $(0.271)$ \\
\hline
\end{tabular}

Note: ${ }^{* * *} \mathrm{p}<0.01,{ }^{* *} \mathrm{p}<0.05, * \mathrm{p}<0.1$. Figures in parenthesis show standard errors

Model -4 includes village fixed effects

Beneficiaries of POPI saw increases in average monthly income, average monthly expenditure and total savings following the MEP intervention. Lower income households saw increases in average monthly income and total savings. Agricultural 
households experienced increase in both average monthly income and expenditure but not savings. Average monthly income and expenditure went up when the household head was educated up to primary level or above. Interestingly, total savings went up when the household head's education was below primary level. Average monthly income and expenditure, total land and savings went up for households which were involved with the implementing partners for less than three years. Households which had not participated in safety net programs had higher monthly income and savings. Joint families saw increased monthly income and expenditure while nuclear families saw higher savings. Female headed households saw higher monthly income while both male and female headed households saw increases in savings.

Table 3. Impact of MEP on food expenditure

\begin{tabular}{lllll}
\hline & Model - 1 & Model - 2 & Model - 3 & Model - 4 \\
\hline Log(Food Expenditure) & Coefficient & Coefficient & Coefficient & Coefficient \\
\hline Gender of household head & $0.260^{* * *}$ & $0.268^{* * *}$ & $0.272^{* * *}$ & $0.272^{* * *}$ \\
& $(0.063)$ & & $(0.061)$ & $(0.060)$ \\
Age of household head & $0.003^{* *}$ & 0.002 & 0.002 & 0.001 \\
& $(0.001)$ & $(0.001)$ & $(0.001)$ & $(0.001)$ \\
Education level of household head & $0.017^{* * *}$ & 0.005 & 0.004 & 0.000 \\
& $(0.004)$ & $(0.004)$ & $(0.004)$ & $(0.004)$ \\
Safety net support & 0.000 & 0.000 & 0.000 & 0.000 \\
& $(0.000)$ & $(0.000)$ & $(0.000)$ & $(0.000)$ \\
Participant = 1, Control = 0 & $0.167^{* * *}$ & $0.116^{* * *}$ & $0.105^{* * *}$ & $0.430^{* *}$ \\
& $(0.041)$ & $(0.040)$ & $(0.040)$ & $(0.192)$ \\
Employment in agri.=0, non-agri.=1) & & $0.071^{* *}$ & $0.071^{* *}$ & 0.039 \\
& & $(0.032)$ & $(0.032)$ & $(0.033)$ \\
Total land & & $0.001^{* * *}$ & $0.001^{* * *}$ & $0.001^{* * *}$ \\
& & $(0.000)$ & $(0.000)$ & $(0.000)$ \\
Is there any electricity in the HH? & & & 0.016 & -0.017 \\
& & & $(0.042)$ & $(0.042)$ \\
Migrate: Yes = 1, No=0 & & & $0.094^{*}$ & 0.058 \\
& & & $(0.052)$ & $(0.067)$ \\
Constant & & $9.964^{* * *}$ & $9.964^{* * *}$ & $9.787^{* * *}$ \\
& & $(0.087)$ & $(0.087)$ & $(0.181)$ \\
\hline
\end{tabular}

Note: ${ }^{* * *} \mathrm{p}<0.01, * * \mathrm{p}<0.05, * \mathrm{p}<0.1$. Figures in parenthesis show standard errors Model -4 includes village fixed effects

Due to the homogenous nature of control and treatment households, it is safe to postulate that mean statistics for both groups are not significantly different (Please see Annex A and B for detailed discussion on homogeneity of the two groups). Though mean comparisons show interesting results, we also derive OLS estimates using village effects to better understand the impact of MEP on income and expenditure. Mostly we have run four models to check for the robustness of the findings. The first model is identifying the treatment effect controlling for basic demographic variables. The second model added land holdings and occupation of the household to purge the impact of income and asset ownerships. The third 
models adds migration dummy to capture the impact of remittances. The fourth model is same as the third one but with additional controls for village fixed effects to purge the village specific idiosyncrasies. The result of the main explanatory variable seems consistent and robust across different specification and dependent variables.

As observed, all coefficients match our prior expectations. The significant coefficient for program participation indicates that treatment households were predicted to have $59 \%$ greater income compared to control households, taking village effects into account. Besides income, MEP has also influenced consumption, especially food expenditure.

Findings from the model imply that food consumption expenditures are predicted to increase by 27.2 percent for the male headed households relative to the female headed households. Holding other things constant, food expenditures are predicted to increase by 43 percent for treatment households.

\section{Table 4. Impact of MEP on savings}

\begin{tabular}{|c|c|c|c|c|}
\hline & Model - 1 & Model - 2 & Model - 3 & Model -4 \\
\hline & Coefficient & Coefficient & Coefficient & Coefficient \\
\hline \multirow[t]{2}{*}{ Gender of household head } & $0.434 * * *$ & $0.468 * * *$ & $0.433^{* * *}$ & $0.319 * *$ \\
\hline & $(0.168)$ & $(0.163)$ & $(0.160)$ & $(0.161)$ \\
\hline \multirow[t]{2}{*}{ Age of household head } & 0.002 & 0.001 & -0.000 & -0.004 \\
\hline & $(0.003)$ & $(0.003)$ & $(0.003)$ & $(0.003)$ \\
\hline \multirow[t]{2}{*}{ Education level of household head } & $0.069 * * *$ & $0.047 * * *$ & $0.042 * * *$ & $0.025 * *$ \\
\hline & $(0.010)$ & $(0.011)$ & $(0.011)$ & $(0.011)$ \\
\hline \multirow[t]{2}{*}{ Safety net support } & -0.000 & $-0.000 *$ & $-0.000 * *$ & $-0.000 *$ \\
\hline & $(0.000)$ & $(0.000)$ & $(0.000)$ & $(0.000)$ \\
\hline \multirow[t]{2}{*}{ Participant $=1$, Control $=0$} & $1.527 * * *$ & $1.442 * * *$ & $1.446 * * *$ & $0.853^{*}$ \\
\hline & $(0.137)$ & $(0.134)$ & $(0.153)$ & $(0.503)$ \\
\hline \multirow[t]{2}{*}{ Employment in agri. $=0$, non-agri. $=1$ ) } & & $0.389 * * *$ & $0.360 * * *$ & $0.276 * * *$ \\
\hline & & $(0.082)$ & $(0.081)$ & $(0.084)$ \\
\hline \multirow[t]{2}{*}{ Total land } & & $0.002 * * *$ & $0.001 * * *$ & $0.002 * * *$ \\
\hline & & $(0.000)$ & $(0.000)$ & $(0.000)$ \\
\hline \multirow[t]{2}{*}{ Is there any electricity in the $\mathrm{HH}$ ? } & & & $0.430 * * *$ & $0.383 * * *$ \\
\hline & & & $(0.105)$ & $(0.107)$ \\
\hline \multirow{2}{*}{ Migrate: $Y e s=1, \mathrm{No}=0$} & & & 0.135 & 0.151 \\
\hline & & & $(0.127)$ & $(0.170)$ \\
\hline \multirow[t]{2}{*}{ Interest in Agri. Bank } & & & $0.069 * *$ & $0.073 * *$ \\
\hline & & & $(0.033)$ & $(0.033)$ \\
\hline \multirow[t]{2}{*}{ Interest rate in commercial bank } & & & $0.078 * * *$ & $0.084^{* * *}$ \\
\hline & & & $(0.026)$ & $(0.026)$ \\
\hline \multirow[t]{2}{*}{ Interest rate in NGOs } & & & -0.000 & $0.019 * *$ \\
\hline & & & $(0.007)$ & $(0.009)$ \\
\hline \multirow[t]{2}{*}{ Constant } & $5.538 * * *$ & $5.466 * * *$ & $5.478 * * *$ & $5.872 * * *$ \\
\hline & $(0.250)$ & $(0.245)$ & $(0.244)$ & $(0.478)$ \\
\hline
\end{tabular}


It is interesting to observe that the inclusion village level specific effects, intensifies the effect of the program. $91.3 \%$ of 750 sample households had access to savings facilities; $99.8 \%$ of households had access to savings facilities whereas only $57.3 \%$ of control households had the same. Despite increased access to savings facilities, $68.83 \%$ of program beneficiaries preferred to save in cash compared to $40 \%$ of non beneficiaries. $52 \%$ of beneficiaries preferred saving with CTS while $40 \%$ preferred POPI. Our mean comparison infers that program households had higher savings than control, which is significant at $1 \%$ level of significance. Using a Probit analysis to check propensity to save, we find that treatment households with the lowest incomes were more likely to save due to association with the MEP program. The same group was also more likely to send their children to school following the intervention. Detailed results have been provided in the annex.

Using a Tobit model, to ascertain the determinants of savings within sample households, we find mixed results. Households were more likely to save if they were headed by a male member, if the household head was educated up to primary level or above and if they were involved in non agricultural occupations. Participation dummy is weakly statistically significant, indicating that MEP did not have much of a strong impact on those households which already had savings.

\section{Discussion and Concluding Remarks}

Our empirical findings lead to a wide variety of inferences; though Plan MEP has been remarkably successful in catalyzing short term solvency for poor households, the program still has a long way to go in terms of alleviating the ultra poor out of poverty. On the brighter side, average income (59\%) as well as average expenditure has risen steeply within the beneficiaries. Lower income households have been able to save more since their association with MEP. Credit facilities have enabled households to engage in more agricultural and non agricultural income generation activities, which have consequentially led to increased food expenditure (43\%). Where high levels of food insecurity and malnutrition is prevalent (World Food Programme, 2012), higher food expenditure is a vital indicator of progress.

The increased propensity to consume and a relatively lower propensity to save among agricultural households are consistent. Possible reasons for such behavior might be the need to consume relatively more food and lack of foresight. The fact that households headed by less educated members were more likely to save compared to educated ones seems counterintuitive. However, this could possibly imply that foresight or the propensity to save is negatively correlated with education (Revoredo \& Morisset, 1999).

Despite every day door to door deposit collections, households which previously had access to savings and credit facilities do not demonstrate significantly higher propensity to save. An important implication of this finding is that increased awareness is essential to encourage higher savings, since savings are essential to ensure the viability of such interventions in the long run. Every day door to door 
collection of loan reimbursement has proved to be successful though, as seen by the rise in overall wellbeing of beneficiaries. Finally questions may be raised as whether flexible credit facilities targeted at individuals are indeed more viable compared to the joint liability process practiced by traditional MFIs.

Our findings indicate a possible threshold in the incremental effects of interventions like MEP. We find income, expenditure and savings to rise significantly for households which have been availing services for less than three years. The same is not observed for sample units engaged for more than three years. On the other hand, possession of assets has also increased significantly. This leads us to a crucial inference: such interventions may not yield desired incremental effects on income after a certain period but the same timeframe provides adequate leverage for asset accumulation. Hence, inherent vulnerability among the most disadvantaged communities can be addressed substantially through interventions like MEP and subsequently improve the living standards of the ultra poor in the long run. In line with the common statement that the poor are bankable, (Yunus, 2004) we therefore conclude that vulnerable communities could benefit largely if MFIs shifted the paradigm from a collective approach to an individualistic approach while developing products and services. Further research could focus on questions regarding the threshold required to provide leverage for asset accumulation as well as possible investment opportunities using flexible savings.

\section{References}

Ahmed, M. M. (2003). Distant voices: The views of the field workers of NGOs in Bangladesh on microcredit. The Geographical Journal, 169(1), 65-74. https://doi.org/10.1111/1475$\underline{4959.04924}$

Bangladesh Bureau of Statistics. (2006). Final Rport on Household Income Expendture Survey - 2005. Dhaka: Bangladesh Bureau of Statistics.

Bangladesh Bureau of Statistics. (2010). Report of the Household Income \& Expenditure Survey 2010. Dhaka: Ministry of Planning.

Basu, P., \& Srivastava, P. (2005). Exploring Possibilities: Microfinance and Rural Credit Access for the Poor in India. Economic and Political Weekly, 1747,1749-1756.

Field, E., Pande, R., Papp, J., \& Rigol, N. (2013). Does the Classic Microfinance Model Discourage Entrepreneurship Among the Poor? Experimental Evidence from India. The American Economic Review, 103(6), 2196-2226. https://doi.org/10.1257/aer.103.6.2196

Ghatak, M., \& Timothy, G. W. (1999). The economics of lending with joint liability: theory and practice. Journal of Development Economics, 60(1), 195-228. https://doi.org/10.1016/S0304-3878(99)00041-3

Giron, J., Hernandez, M., \& Castaneda, J. (2004). Participatory methodologies and the prouct development process: the experience of Mixtec craftswomen in Mexico. Development in Practice, 14(3), 396-406. https://doi.org/10.1080/0961452042000191213a 
Flexible Micro Finance Program: Effectiveness and Efficiency To Reach The Extreme Poor

Guérin, I. (2014). Juggling with Debt, Social Ties, and Values: The Everyday Use of Microcredit in Rural South India. Current Anthropology, 55(S9), 40-50. https://doi.org/10.1086/675929

Hamad, M., \& Duman, T. (2013). An Evaluation of Micro-Credit Programs in Bosnia and Herzegovina Using Porter's Diamond Model. Eurasian Journal of Business and Economics, 6(12), 27-42.

Khan, A., \& Rabbani, A. (2015). Assessing the Spatial Accessibility of Microfinance in Northern Bangladesh: A GIS Analysis. Journal of Regional Science, 55(5), 842-870.

Lewis, M., Welsh, M., Dehler, G., \& Green, S. (2002). Product Development Tensions: Exploring Contrasting Styles of Project Management. The Academy of Management Journal, 45(3), 546-564. https://doi.org/10.2307/3069380

Matin, I., \& Hulme, D. (2003). Programs for the Poorest: Learning from the IGVGD Program in Bangladesh. World Development, 31(3), 647-665. https://doi.org/10.1016/S0305750X(02)00223-1

Meyer, R. L. (2002). The Demand for Flexible Microfinance Products: Lessons from Bangladesh. Journal of International Development. 14(3), 351-368. https://doi.org/10.1002/jid.884

Microcredit Regulatory Authority. (2015). An Overview of Microcredit in Bangladesh. Retrieved June 2, 2016, from http://www.mra.gov.bd/index.php?option=com_content\&view=article\&id=104\&ltemid=80

Microcredit Regulatory Authority. (2016, May 12). License Info of NGO MFIs. Retrieved June 2, 2016, from http://www.mra.gov.bd/index.php?option=com_content\&view=article\&id=115\&ltemid=95

Olofsgard, A. (2014). Randomized Controlled Trials: Strengths, Weaknesses and Policy Relevance. Stockholm: Elanders Sverige $A B$.

Rahman, A., \& Razzaque, A. (2000). On reaching the hard core poor: some evidence on social exclusion in NGO programs. The Bangladesh Development Studies, 26(1), 1-36.

Rahman, H. Z. (1998). Bangladesh: Dynamics of Rural Poverty. International Conference on Poverty, (pp. 9-11). Dhaka.

Revoredo, C., \& Morisset, J. (1999). Savings and Education: A Life-Cycle Model Applied to a Panel of 74 Countries. World Bank Policy Research Working Papers.

Seibel, H. D., Rachmadi, A., \& Kusumayakti, D. (2010). Reform, Growth and Resileince of Savings led Commercial Microfinance Institutions: The Case of the Microbanking Units of Bank Rakyat Indonesia. Savings and Development, 34(3), 277-303.

Sriram, M. S., \& Parhi, S. (2006). Financial Status of Rural Poor: A Study in Udaipur District. Economic and Political Weekly, 41(51), 5269-5275.

Ssewamala, F. M., \& Sherraden, M. (2004). Integrating Saving into Microenterprise Programs for the Poor: Do Institutions Matter? Social Service Review, 78(3), 404-429.

Vonderlac, R. M., \& Schreine, J. (2002). Women, microfinance and savings: Lessons and Proposals. Development in Practice, 12(5), 602-612. https://doi.org/10.1080/0961452022000017614

World Bank. (2011). World Development Indicators. Retrieved June 2, 2016, from URL: http://data.worldbank.org/data-catalog/world-development-indicators?cid=GPD_WDI

World Food Programme. (2012). WFP Bangladesh: Nutrition Strategy 2012-2016. Dhaka: World Food Programme.

Yunus, M. (2004). Grameen Bank, Microcredit and Millenium Development Goals. Economic and Political Weekly, 39(36), 4077-4080. 


\section{Annex A}

Discussion on Control and Treatment Households: To identify the unbiased treatment effect, homogeneity between the treatment and control households is absolutely crucial in all respect apart from the treatment in question.

In order to ascertain the similarity between the two groups, we first look at the social characteristics of the households such as access to pure drinking water, access to hygienic latrine etc. Secondly, we move forward to the family characteristics such as family size, family structure, and characteristics of household head. Thirdly, we focus on the asset structure (financial and physical). We structure our analysis in two ways- first, we compare the characteristics of participants and non-participants, and second, we compare the characteristics of five wealth-based groups of PLAN with control households. The latter comparison will enable us further effectively to assess impacts compared to the control group.

Background and Socioeconomic Conditions of Households: The overall wellbeing of the households depends on the socioeconomic characteristics of a household to a great extent such as education level, gender, age of the of household head, access to electricity, access to pure drinking water and access to hygiene latrine facility etc.

Table A1 exhibits that all the control households have access to pure drinking water from tube-well, while 98.50 percent participant households uses tube-well water for their daily usages.

\section{Table A1. Social Characteristics of Households By Participation Status}

\begin{tabular}{lll}
\hline Social Characteristics & Participants & Control \\
\hline Sources of water & $\%$ & $\%$ \\
\hline Tube-well & 98.50 & 100.00 \\
Other & 1.50 & 0.00 \\
\hline Type of latrine & & \\
\hline Pacca & 3.67 & 1.33 \\
Slab & 71.33 & 80.67 \\
Kacha & 20.00 & 6.00 \\
Open & 5.00 & 12.00 \\
\hline Electricity & & \\
\hline Yes & 20.17 & 14.00 \\
No & 79.83 & 86.00 \\
\hline Total & 600 & 150 \\
\hline
\end{tabular}

Source: Household Survey Data

Only 1.50 percent of the participant households get water from other sources like water from pond and tap. There is a slight difference between participants and control in using the latrine type. Most of the participant and control households have access to hygiene latrines and very small number of households has no latrine facility. Access to electricity is another feature of households. The data reveals that about 20 percent of the participant households have access to electricity as compared to about 14 percent of the control households.

Now let us turn to the family characteristics. We observed that most of the households (around 92 percent) are headed by male (Table A2). 
Flexible Micro Finance Program: Effectiveness and Efficiency To Reach The Extreme Poor

Table A2. Gender of the Household Heads by Participation Status

\begin{tabular}{lcccc}
\hline Household Head & Control & Participants & \multicolumn{2}{c}{ Total } \\
\hline Gender & Percent & Percent & $\mathrm{N}$ & Percent \\
\hline Male & 92 & 93.5 & 699 & 93.2 \\
Female & 08 & 6.5 & 51 & 6.8 \\
\hline Total & 100 & 100 & 750 & 100 \\
\hline
\end{tabular}

Source: Household Survey Data

It further shows that only around seven percent of the households are headed by female. Although there are some differences in the gender based structure of the households by participation status in the PLAN program, the differences are not statistically significant. This is expected. This data restates the traditional male dominant family structure of Bangladesh, irrespective of participation in the microfinance programs. Program may impact family size of the participating households if use of contraceptive or awareness program for small family enters into programs design. This is not the case. Plan program does not have any such module. Therefore, any difference in the family size, if any, will be due to external factors or targeted program placement among the households with large or small family size.

Table A3 presents distribution of the family size by participation status. Participating households have higher family size. About 38 the participating households had family size between five to six as against only 21 the non-participants. Apart from the first category of 1-2 and 5-6 members, the family size is more or less same uniform between the treatment and control groups. The household head plays a crucial role in the household decision making process. So, we have tried to analyze the age and education of household head.

Table A3. Distribution of the Family Size by Participation Status

\begin{tabular}{lccc}
\hline Family Size & Control & Participants & Total \\
\hline $1-2$ & 17.33 & 6.0 & 8.27 \\
$3-4$ & 52.67 & 49.17 & 49.87 \\
$5-6$ & 21.33 & 38.5 & 35.07 \\
Above 6 & 8.67 & 6.33 & 6.8 \\
\hline Total & 150 & 600 & 750
\end{tabular}

Source: Household Survey Data

The age distribution of the household heads is reported in Table 4.

Table A4. Distribution of Age of the Household Heads by Participation Status

\begin{tabular}{lccc}
\hline Age Category & Non-Participants & Participants & Total \\
\hline Below 20 & 0.67 & 0.33 & 0.4 \\
$20-30$ & 16 & 22.17 & 20.93 \\
$30-40$ & 29.33 & 34.83 & 33.73 \\
$40-50$ & 25.33 & 18.83 & 20.13 \\
$50-60$ & 17.33 & 9.83 & 11.33 \\
Above 60 & 11.33 & 14 & 13.47 \\
\hline Total & 150 & 600 & 750 \\
\hline
\end{tabular}

It shows that 76 percent of the program participants and around 71 percent of the control group household heads are aged from 20 to 50 . This is important to notice that people in this age range have the ability to generate income by selling physical labor or working 
otherwise. This group has much higher physical and mental ability and strength to earn compared to the people aged above 50.

Education of household head is an indicator of human capital of the household and this is well established that investment in human capital is a sustainable strategy for poverty alleviation in both short and long run.

Almost all the sample household heads had formal schooling, at least primary education (Table A5). Only around 0.50 percent of the household heads had no education. Among the participants, around 36 percent had schooling of more than 3 years while it was 28 percent for control.

Table A5. Distribution of Schooling Years of the Household Heads by Participation Status

\begin{tabular}{lccc}
\hline Schooling year & Control & Participants & Total \\
\hline Zero & 2.67 & 0 & 0.53 \\
$1-2$ & 21.33 & 15.83 & 16.93 \\
$2-3$ & 48 & 47.67 & 47.73 \\
Above 3 & 28.0 & 36.5 & 43.80 \\
\hline Total & 150 & 600 & 750 \\
\hline
\end{tabular}

Homestead Land: Not all households have their own homestead. They live on the premises of other households. Around 8.5 percent of the households do not own their homestead. Among the control households, around 11 percent do not own their homestead. However, the pattern is little different, as expected, among the participants. Following the wealth based ranking of the participating households, it appears that around 14 percent of the households in group E are absolute landless. About 75 percent of the households in this group is either landless or have homestead land of up to 5 decimal. In contrast, it was only 8 percent for the households in group A. The clearer picture emerges when we compare mean homestead land holding of different groups including control households. Average homestead land size of the households in group E was around 4.5 decimal compared to around 31 decimals for group A.

Table A6. Distribution of Homestead Land by Participation Status and Type

\begin{tabular}{|c|c|c|c|c|c|c|c|}
\hline & A & B & C & D & $\mathrm{E}$ & Control & Total \\
\hline Decimal & \multicolumn{7}{|c|}{ Homestead } \\
\hline No land & 0 & 5.41 & 2.92 & 6.01 & 13.71 & 10.67 & 8.4 \\
\hline $0-5$ & 8.33 & 13.51 & 39.77 & 58.66 & 51.55 & 52 & 49.07 \\
\hline $10-15$ & 25 & 8.11 & 9.94 & 6.01 & 6.19 & 7.33 & 7.6 \\
\hline $15-20$ & 8.33 & 8.11 & 4.09 & 3.18 & 4.12 & 3.33 & 3.87 \\
\hline $20-40$ & 25 & 16.22 & 9.94 & 2.12 & 0 & 2.67 & 4.8 \\
\hline Above 40 & 8.33 & 10.81 & 4.09 & 0.35 & 0 & 0 & 1.73 \\
\hline Col \% & 100 & 100 & 100 & 100 & 100 & 100 & 100 \\
\hline
\end{tabular}

The control households have homestead land around 6 decimals. Since households in group A have more wealth than other groups, and E group households have least wealth, indeed an inverse relationship exists between homestead landholding and ranking of the households. However, it should be noted here that average homestead of the participants does not necessarily represent the pre-program level because of possible program effects. 
Food Expenditures: It is often argued that higher income leads to higher level of consumption. But sometimes, it is plausible that a household can increase its consumption expenditure even without increasing income with greater access to external credit. We have seen in the paper that annual average income of the participating households is higher than the non-participants. But it is also correct to note that most of the participants are borrowers. Table A7 shows the distribution of food expenditure by participation status. The control households had relatively lowest amount of food consumption. Around ninety percent of the control households had annual consumption expenditure of Tk.50,000 or less, as against seventy percent of the households in group $\mathrm{E}$.

Table A7. Distribution of Food Expenditures by Participation Status and Type

\begin{tabular}{cccccccc}
\hline Col \% & \multicolumn{7}{c}{ Food expenditure } \\
\cline { 2 - 8 } & A & B & C & D & E & Control & Total \\
\hline $0-25000$ & 16.67 & 2.7 & 14.62 & 21.2 & 18.56 & 28.67 & 19.87 \\
$25000-50000$ & 41.67 & 59.46 & 53.22 & 61.48 & 58.76 & 61.33 & 58.8 \\
Above 50000 & 41.67 & 37.84 & 32.17 & 17.31 & 22.68 & 10 & 21.33 \\
Total & 100 & 100 & 100 & 100 & 100 & 100 & 100 \\
\hline
\end{tabular}

This was around 60 percent for the households in group A. Obviously the relatively wealthy households will have higher level of food consumption. It is not income alone but also family size that will influence food consumption expenditure, ceteris paribus.

Average food expenditure, as discussed above, will be higher for the households in group A as they have higher income and wealth, and the lower among the participants are the households in group E (Figure-A1). The control households have lowest average annual income. The participants are better off. This may be due to participation in micro credit and other characteristic differences.

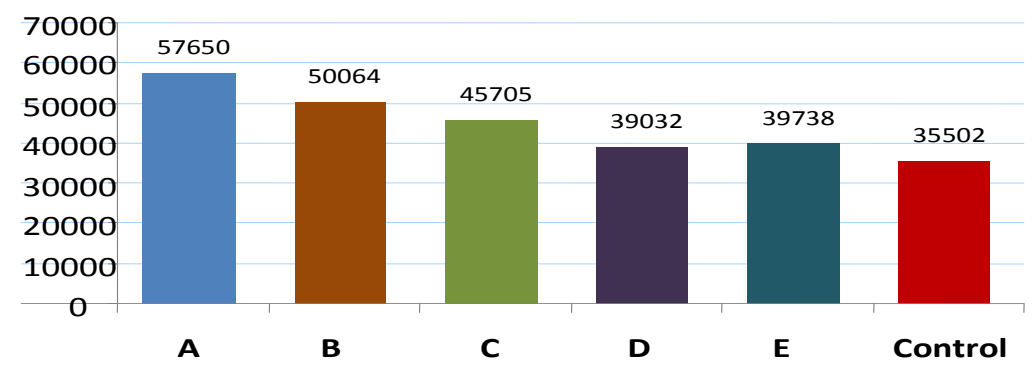

Figure A1. Mean Food Expenditure (Taka)

Safety Net Programs: Social safety net programs are basically aimed to support the poor and vulnerable households. Safety net programs are primarily imposed by the government in the rural areas through which households can gather some cash to smooth their living condition. Government run social safety net programs include Vulnerable Group Development (VGD), Vulnerability Group Feeding (VGF), and Food for Work (FFW) etc. these programs provide mainly temporary support to the poor households. The targeting of these programs of the government is largely under question due to the government mismanagement and political motivation of the local government officials. This was quite evident from the survey experience gathered talking to the inhabitants of the sampled are. Thus, the success of these 
programs in terms of coverage of poor people and effectiveness to reduce poverty is largely questionable.

Table A8. Access to Social Safety Net Programs by Participation Status and Type

\begin{tabular}{|c|c|c|c|c|c|c|c|}
\hline Col \% & $A$ & $\mathrm{~B}$ & C & D & $\mathrm{E}$ & Control & Total \\
\hline \multicolumn{8}{|c|}{ Access to Social Safety Net } \\
\hline No & 100 & 83.78 & 85.38 & 79.51 & 89.69 & 72 & 81.2 \\
\hline Yes & 0 & 16.22 & 14.62 & 20.49 & 10.31 & 28 & 18.8 \\
\hline Total & 100 & 100 & 100 & 100 & 100 & 100 & 100 \\
\hline
\end{tabular}

Realizing the fact above, it is certainly important to see the coverage of social safety net programs in the sampled area. This will help us determine who receives support and who does not that in turn will help in targeting the left out households that require support. Although across all groups 80 percent or more households do not receive any social safety net support or stipends, as much as 90 percent of the Extreme Poor (Category E) and among D group households almost 80 percent do not receive such supports (Table-8). Among the controls 72 percent do not receive such benefit. This large proportion of people is left out from any type of government support that has put them into poverty trap.

Critical Findings and Concluding Notes: We investigate the characteristics of treatment and control household in three key areas: demographic and family characteristics, asset characteristics, and expenditure characteristics.

Participants and non-participants do not show unusual difference in many characteristics including age of the household held, household head gender, and family size. Although microfinance participation is expected to reduce the family size through health and family planning related social programs and interventions, the case was not so. This is perhaps due to the unavailability of such features in the product of Plan and separate social programs applied to the same households. It is found that education level on average is the lowest for control or non-participant households and shows the highest value for category ' $A$ ' households.

Landholding, either homestead or agricultural, is very low for the control or non-participants as expected. Essentially, among the participants it decreases as we move across from $A$ to $E$ or better off to worse off households. There is a decreasing trend of average total income with respect to the wealth rank of the households explains why expenditures either for food or non-food purpose also follows the same trend. Lower income certainly induces to consume less.

Finally, a very critical finding is that social safety nets do not reach out most of these poor households. Around $80 \%$ households on average, regardless of wealth rank, do not receive safety net benefits. This proportion is higher for the poorer household categories $D$ or $E$.

As a final note, the households in both the participant or control villages do not have much divergence in terms of family demographic characteristics. But yet they diverge to some extent in terms of their economic condition. Control households are largely lagging behind in every economic variables or characteristics discussed here. Participants are far better off compared to the non-participants. This wide gap may be largely attributable to the participation in the microfinance programs. Thus there is no discernible statistical difference between the two groups in demographic characteristics, making the control households a valid comparison group. There is statistically significant difference between the two groups in terms of economics variables which is highly correlated to program participation and is the subject of investigation in this paper. 
Flexible Micro Finance Program: Effectiveness and Efficiency To Reach The Extreme Poor

\section{Annex B}

Table B1. $t$ test for mean difference before and after association with CTS and POPI (Organization)

\begin{tabular}{|c|c|c|c|c|c|c|c|c|}
\hline Items & Organization & Frequency & $\begin{array}{l}\text { Current } \\
\text { (Mean) }\end{array}$ & SE & $\begin{array}{l}\text { Before } \\
\text { (Mean) }\end{array}$ & SE & Dif. & t state \\
\hline Average & CTS & 278 & 6886.338 & 367.855 & 6021.788 & 561.39 & 864.5504 & 1.6159 \\
\hline $\begin{array}{l}\text { Monthly } \\
\text { Income }\end{array}$ & POPI & 121 & 5763.851 & 450.7357 & 5160.331 & 423.4703 & 603.5207 & 2.2169 \\
\hline Average & CTS & 239 & 5034.653 & 483.0896 & 4377.448 & 533.7814 & 657.205 & 1.4774 \\
\hline $\begin{array}{l}\text { Monthly } \\
\text { Expenditure }\end{array}$ & POPI & 120 & 4457.55 & 279.339 & 4094.067 & 252.7877 & 363.4833 & 4.8315 \\
\hline Agricultural & CTS & 250 & 63.764 & 24.29192 & 44.92 & 6.4391 & 18.844 & 0.8755 \\
\hline Land & POPI & 121 & 93.76446 & 34.38621 & 93.26033 & 34.37988 & 0.504132 & 1.2105 \\
\hline Household & CTS & 269 & 18.47491 & 11.18669 & 8.004647 & 1.222174 & 10.47026 & 1.0383 \\
\hline Land & POPI & 120 & 9.43125 & 1.086587 & 9.414583 & 1.084965 & 0.016667 & 0.1672 \\
\hline \multirow[t]{2}{*}{ Total Savings } & CTS & 236 & 6705.538 & 1262.009 & 4870.369 & 1086.295 & 1835.169 & 1.7842 \\
\hline & POPI & 121 & 5071.38 & 753.9003 & 3431.785 & 981.8197 & 1639.595 & 2.0032 \\
\hline
\end{tabular}

Table B2. $t$ test for mean difference before and after association with CTS and POPI (Income group)

\begin{tabular}{|c|c|c|c|c|c|c|c|c|}
\hline Items & $\begin{array}{l}\text { Income } \\
\text { group }\end{array}$ & Frequency & $\begin{array}{l}\text { Current } \\
\text { (Mean) }\end{array}$ & SE & $\begin{array}{c}\text { Before } \\
\text { (Mean) }\end{array}$ & SE & Dif. & t state \\
\hline Average Monthly & rich & 31 & 8227.29 & 1458.737 & 8016.129 & 1250.695 & 211.1613 & 0.203 \\
\hline Income & poor & 368 & 6404.299 & 290.5637 & 5570.535 & 432.8995 & 833.7636 & 2.0607 \\
\hline Average Monthly & rich & 30 & 5836.367 & 747.1573 & 5510 & 652.7105 & 326.3667 & 1.3812 \\
\hline Expenditure & poor & 329 & 4751.055 & 358.8694 & 4170.815 & 393.46 & 580.2401 & 1.7936 \\
\hline \multirow[t]{2}{*}{ Agricultural Land } & rich & 31 & 354.9032 & 190.7699 & 183.2903 & 35.8075 & 171.6129 & 1.0039 \\
\hline & poor & 340 & 47.89559 & 12.30512 & 49.50735 & 12.57735 & -1.61177 & -0.5981 \\
\hline \multirow[t]{2}{*}{ Household Land } & rich & 31 & 16.16129 & 2.754506 & 15.77419 & 2.728468 & 0.387097 & 0.4904 \\
\hline & poor & 358 & 15.64385 & 8.409467 & 7.804469 & 0.952381 & 7.839385 & 1.0346 \\
\hline \multirow[t]{2}{*}{ Total Savings } & rich & 31 & 18760.16 & 7610.606 & 19234.52 & 7542.822 & -474.355 & -0.0813 \\
\hline & poor & 326 & 4952.696 & 595.1824 & 2970.5 & 425.7806 & 1982.196 & 3.3741 \\
\hline
\end{tabular}

Table B3. $t$ test for mean difference before and after association with CTS and POPI (Employment)

\begin{tabular}{|c|c|c|c|c|c|c|c|c|}
\hline Items & Employment & Frequency & $\begin{array}{l}\text { Current } \\
\text { (Mean) }\end{array}$ & SE & $\begin{array}{l}\text { Before } \\
\text { (Mean) }\end{array}$ & SE & Dif. & t state \\
\hline Average & Agriculture & 227 & 5734.824 & 369.2121 & 4723.952 & 435.2898 & 1010.872 & 2.2982 \\
\hline Monthly Income & Non-agriculture & 172 & 7616.413 & 456.7735 & 7128.605 & 752.3733 & 487.8081 & 0.7289 \\
\hline Average & Agriculture & 214 & 4015.07 & 157.3759 & 3414.453 & 139.0061 & 600.6168 & 12.6429 \\
\hline \multicolumn{8}{|l|}{ Expenditure } & 0.6783 \\
\hline \multirow[t]{2}{*}{ Agricultural Land } & Agriculture & 203 & 73.51478 & 29.81913 & 51.30788 & 7.734664 & 22.2069 & 0.8378 \\
\hline & Non-agriculture & 168 & 73.58929 & 24.9849 & 72.01786 & 24.93306 & 1.571429 & 1.873 \\
\hline \multirow[t]{2}{*}{ Household Land } & Agriculture & 221 & 7.840498 & 0.794167 & 7.516968 & 0.732509 & 0.323529 & 1.0499 \\
\hline & Non-agriculture & 168 & 26.00446 & 17.89384 & 9.653274 & 1.870253 & 16.35119 & 1.0129 \\
\hline \multirow[t]{2}{*}{ Total Savings } & Agriculture & 203 & 5055.33 & 1282.605 & 3256.581 & 776.612 & 1798.749 & 1.9405 \\
\hline & Non-agriculture & 154 & 7596.831 & 1105.043 & 5867.318 & 1517.777 & 1729.513 & 1.4577 \\
\hline
\end{tabular}


Meherun AHMED, Baqui KHALILY, Abdul KHALEQUE \& Syeda Nafisa NAWAL

Table B4. $t$ test for mean difference before and after association with CTS and POPI (Education)

\begin{tabular}{lcccccccc}
\hline \hline Items & $\begin{array}{l}\text { Education of the Frequency } \\
\text { household head }\end{array}$ & $\begin{array}{l}\text { Current } \\
\text { (Mean) }\end{array}$ & SE & $\begin{array}{l}\text { Before } \\
\text { (Mean) }\end{array}$ & SE & Dif. & t state \\
\hline $\begin{array}{l}\text { Average Monthly } \\
\text { Income }\end{array}$ & $\begin{array}{c}\text { Below primary } \\
\text { Primary of More }\end{array}$ & 293 & 6309.693 & 346.7763 & 5708.386 & 536.3678 & 601.3072 & 1.1899 \\
\hline Average Monthly & Below primary & 268 & 4198.943 & 529.9986 & 5904.717 & 456.447 & 1294.226 & 3.8771 \\
\hline Expenditure & Primary of More & 91 & 5113.604 & 618.8781 & 3721.692 & 232.8724 & 1391.912 & 2.393 \\
\hline Agricultural Land & Below primary & 268 & 67.9944 & 27.06138 & 47.58022 & 15.62786 & 20.41418 & 1.0322 \\
& Primary of More & 103 & 88 & 12.12296 & 94.78641 & 14.77001 & -6.78641 & -0.7674 \\
\hline Household Land & Below primary & 283 & 7.109541 & 0.568685 & 6.782686 & 0.513516 & 0.326855 & 1.3453 \\
& Primary of More & 106 & 38.58019 & 28.34648 & 12.86321 & 3.008871 & 25.71698 & 1.0052 \\
\hline Total Savings & Below primary & 251 & 5836.462 & 1123.897 & 3158.482 & 550.6927 & 2677.98 & 3.3874 \\
& Primary of More & 106 & 6898.038 & 1252.108 & 7281.83 & 2308.435 & -383.793 & -0.2399 \\
\hline
\end{tabular}

Table B5. $t$ test for mean difference before and after association with CTS and POPI (Duration of membership)

\begin{tabular}{lcccccccc}
\hline \hline Items & $\begin{array}{c}\text { Duration of } \\
\text { membership }\end{array}$ & Frequency & $\begin{array}{c}\text { Current } \\
\text { (Mean) }\end{array}$ & SE & $\begin{array}{c}\text { Before } \\
\text { (Mean) }\end{array}$ & SE & Dif. & t stat \\
\hline Average Monthly & Less than 3 years & 222 & 6209.523 & 322.5007 & 4972.779 & 259.5048 & 1236.743 & 10.882 \\
Income & 3 or more years & 177 & 6967.876 & 516.7015 & 6748.588 & 865.2278 & 219.2881 & 0.2587 \\
\hline Average Monthly & Less than 3 years & 192 & 4419.641 & 254.5163 & 3795.786 & 173.8887 & 623.8542 & 3.082 \\
Expenditure & 3 or more years & 167 & 5327.048 & 657.013 & 4842.557 & 757.7884 & 484.491 & 0.8132 \\
\hline Agricultural Land & Less than 3 years & 207 & 35.78744 & 5.007374 & 35.0628 & 4.849738 & 0.724638 & 1.1616 \\
& 3 or more years & 164 & 121.2104 & 44.2059 & 93.02744 & 26.39456 & 28.18293 & 0.8589 \\
\hline Household Land & Less than 3 years & 215 & 6.713953 & 0.583396 & 6.602326 & 0.583351 & 0.111628 & 2.7963 \\
& 3 or more years & 174 & 26.77011 & 17.28254 & 10.70977 & 1.888701 & 16.06034 & 1.0302 \\
\hline Total Savings & Less than 3 years & 199 & 5507.643 & 854.6935 & 3477.96 & 652.0308 & 2029.683 & 2.6293 \\
& 3 or more years & 158 & 6962.804 & 1653.558 & 5522.399 & 1587.151 & 1440.405 & 1.0707 \\
\hline
\end{tabular}

Table B6. $t$ test for mean difference before and after association with CTS and POPI (Safety Net)

\begin{tabular}{|c|c|c|c|c|c|c|c|c|}
\hline Items & $\begin{array}{l}\text { Participation in } \\
\text { Safety-net prog } \\
\end{array}$ & Frequency & $\begin{array}{l}\text { Current } \\
\text { (Mean) } \\
\end{array}$ & SE & $\begin{array}{l}\text { Before } \\
\text { (Mean) }\end{array}$ & SE & Dif. & t stat \\
\hline Average Monthly & $\begin{array}{ll}y & \mathrm{NO}\end{array}$ & 327 & 6719.321 & 329.7513 & 5528.859 & 350.5416 & 1190.462 & 3.6576 \\
\hline Income & YES & 72 & 5758.472 & 598.388 & 6812.778 & 1639.392 & -1054.31 & -0.7018 \\
\hline Average Monthly & NO & 299 & 4703.746 & 255.9298 & 4109.274 & 322.6547 & 594.4716 & 1.6839 \\
\hline Expenditure & YES & 60 & 5529.467 & 1553.699 & 5147.083 & 1484.003 & 382.3833 & 1.4788 \\
\hline \multirow[t]{2}{*}{ Agricultural Land } & NO & 307 & 66.41205 & 14.05306 & 67.98534 & 14.3382 & -1.57329 & -0.5292 \\
\hline & YES & 64 & 107.7813 & 93.61096 & 25.67188 & 11.42221 & 82.10938 & 0.9912 \\
\hline \multirow[t]{2}{*}{ Household Land } & NO & 320 & 17.4125 & 9.406135 & 8.825 & 1.086687 & 8.5875 & 1.0133 \\
\hline & YES & 69 & 7.673913 & 1.341 & 6.652174 & 0.905387 & 1.021739 & 1.0376 \\
\hline \multirow[t]{2}{*}{ Total Savings } & NO & 293 & 5734.369 & 702.4128 & 4232.089 & 892.8849 & 1502.28 & 2.0712 \\
\hline & YES & 64 & 8062.094 & 3669.745 & 5072.672 & 1678.611 & 2989.422 & 1.2442 \\
\hline
\end{tabular}


Flexible Micro Finance Program: Effectiveness and Efficiency To Reach The Extreme Poor

Table B7: $t$ test for mean difference before and after association with CTS and POPI (Family Type)

\begin{tabular}{|c|c|c|c|c|c|c|c|c|}
\hline Items & $\begin{array}{l}\text { Family } \\
\text { Type }\end{array}$ & Frequency & $\begin{array}{l}\text { Current } \\
\text { (Mean) }\end{array}$ & SE & $\begin{array}{l}\text { Before } \\
\text { (Mean) }\end{array}$ & SE & Dif. & t state \\
\hline \multirow{2}{*}{$\begin{array}{l}\text { Average Monthly } \\
\text { Income }\end{array}$} & Joint & 95 & 7566.621 & 615.4153 & 5968.495 & 464.2255 & 1598.126 & 7.6327 \\
\hline & Nucleus & 304 & 6226.97 & 328.9023 & 5695.559 & 521.028 & 531.4112 & 1.0716 \\
\hline \multirow{2}{*}{$\begin{array}{l}\text { Average Monthly } \\
\text { Expenditure }\end{array}$} & Joint & 90 & 4969.644 & 327.761 & 4099.333 & 262.6187 & 870.3111 & 4.0537 \\
\hline & Nucleus & 269 & 4798.959 & 433.5896 & 4344.082 & 479.4133 & 454.8773 & 1.1665 \\
\hline \multirow[t]{2}{*}{ Agricultural Land } & Joint & 90 & 133.3778 & 67.14555 & 83.15556 & 17.69092 & 50.22222 & 0.8393 \\
\hline & Nucleus & 281 & 54.38612 & 14.88685 & 53.48932 & 14.85695 & 0.896797 & 1.6702 \\
\hline \multirow[t]{2}{*}{ Household Land } & Joint & 93 & 10.42742 & 1.424848 & 10.28763 & 1.42445 & 0.139785 & 1.3848 \\
\hline & Nucleus & 296 & 17.33699 & 10.16619 & 7.858953 & 1.106353 & 9.478041 & 1.0342 \\
\hline \multirow[t]{2}{*}{ Total Savings } & Joint & 88 & 8671.33 & 2847.428 & 5536.307 & 1714.927 & 3135.023 & 1.4312 \\
\hline & Nucleus & 269 & 5327.387 & 686.5486 & 4005.42 & 888.6867 & 1321.967 & 2.0015 \\
\hline
\end{tabular}

Table B8: $t$ test for mean difference before and after association with CTS and POPI (Gender)

\begin{tabular}{lcccccccc}
\hline Items & $\begin{array}{c}\text { Gender of Household Frequency } \\
\text { Head }\end{array}$ & $\begin{array}{c}\text { Current } \\
\text { (Mean) }\end{array}$ & SE & $\begin{array}{c}\text { Before } \\
\text { (Mean) }\end{array}$ & SE & Dif. & t state \\
\hline Average Monthly & Female & 26 & 4059.231 & 693.6633 & 3448.846 & 521.6496 & 610.3846 & 2.1113 \\
Income & Male & 373 & 6719.271 & 305.9893 & 5921.681 & 437.9218 & 797.5898 & 1.956 \\
\hline Average Monthly & Female & 26 & 3308.962 & 461.1313 & 2965.692 & 363.1539 & 343.2692 & 1.8235 \\
Expenditure & Male & 333 & 4961.426 & 358.5349 & 4385.556 & 392.0355 & 575.8709 & 1.7997 \\
\hline Agricultural Land & Female & 27 & 180.0741 & 147.5768 & 180.8889 & 147.5428 & -0.81481 & -1.2143 \\
& Male & 344 & 65.1875 & 18.02985 & 51.25145 & 5.988436 & 13.93605 & 0.8911 \\
\hline Household Land & Female & 26 & 8.730769 & 2.330769 & 8.730769 & 2.330769 & 0 &. \\
& Male & 363 & 16.1832 & 8.294477 & 8.418733 & 0.960087 & 7.764463 & 1.039 \\
\hline Total Savings & Female & 27 & 2330.852 & 577.1745 & 1145 & 517.0147 & 1185.852 & 2.4284 \\
& Male & 330 & 6464.276 & 940.9935 & 4647.691 & 853.6304 & 1816.585 & 2.2916 \\
\hline
\end{tabular}

\section{Table B9: $t$ test for mean difference before and after association with CTS and POPI (Migration)}

\begin{tabular}{lcclcllll}
\hline \hline Items & $\begin{array}{l}\text { A family } \\
\text { member } \\
\text { migrated }\end{array}$ & Frequency & $\begin{array}{l}\text { Current } \\
\text { (Mean) }\end{array}$ & SE & \multicolumn{1}{c}{$\begin{array}{l}\text { Before } \\
\text { (Mean) }\end{array}$} & SE & Dif. & t state \\
\hline $\begin{array}{l}\text { Average Monthly } \\
\text { Income }\end{array}$ & NO & 373 & 6594.984 & 307.421 & 5830.18 & 438.097 & 764.8043 & 1.8754 \\
\hline Average Monthly & YES & 26 & 5842.269 & 732.8637 & 4761.538 & 652.1698 & 1080.731 & 4.03 \\
Expenditure & YES & 22 & 39773.045 & 562.2227 & 4392.045 & 700.2539 & -419 & -0.6533 \\
\hline Agricultural Land & NO & 347 & 77.79683 & 21.18135 & 64.00144 & 12.86178 & 13.79539 & 0.8898 \\
& YES & 24 & 12.125 & 4.848544 & 12.75 & 4.959711 & -0.625 & -1 \\
\hline Household Land & NO & 364 & 16.3489 & 8.272546 & 8.627747 & 0.969316 & 7.721154 & 1.0361 \\
& YES & 25 & 6.02 & 0.857555 & 5.7 & 0.719954 & 0.32 & 1 \\
\hline Total Savings & NO & 332 & 5848.774 & 863.8406 & 4249.105 & 833.3811 & 1599.669 & 2.2598 \\
& YES & 25 & 10174.04 & 4891.656 & 6158 & 2309.336 & 4016.04 & 0.8562 \\
\hline
\end{tabular}


Meherun AHMED, Baqui KHALILY, Abdul KHALEQUE \& Syeda Nafisa NAWAL

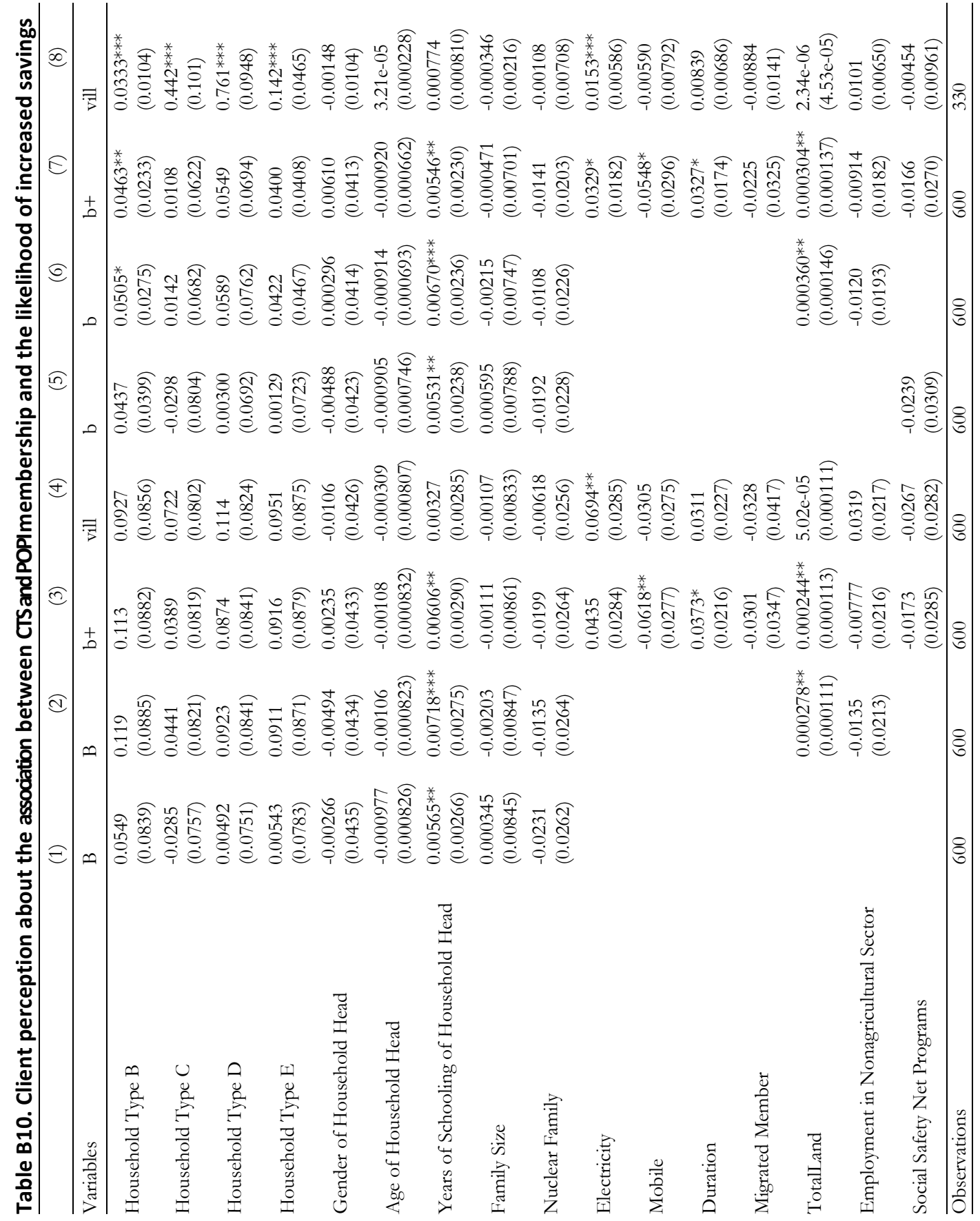




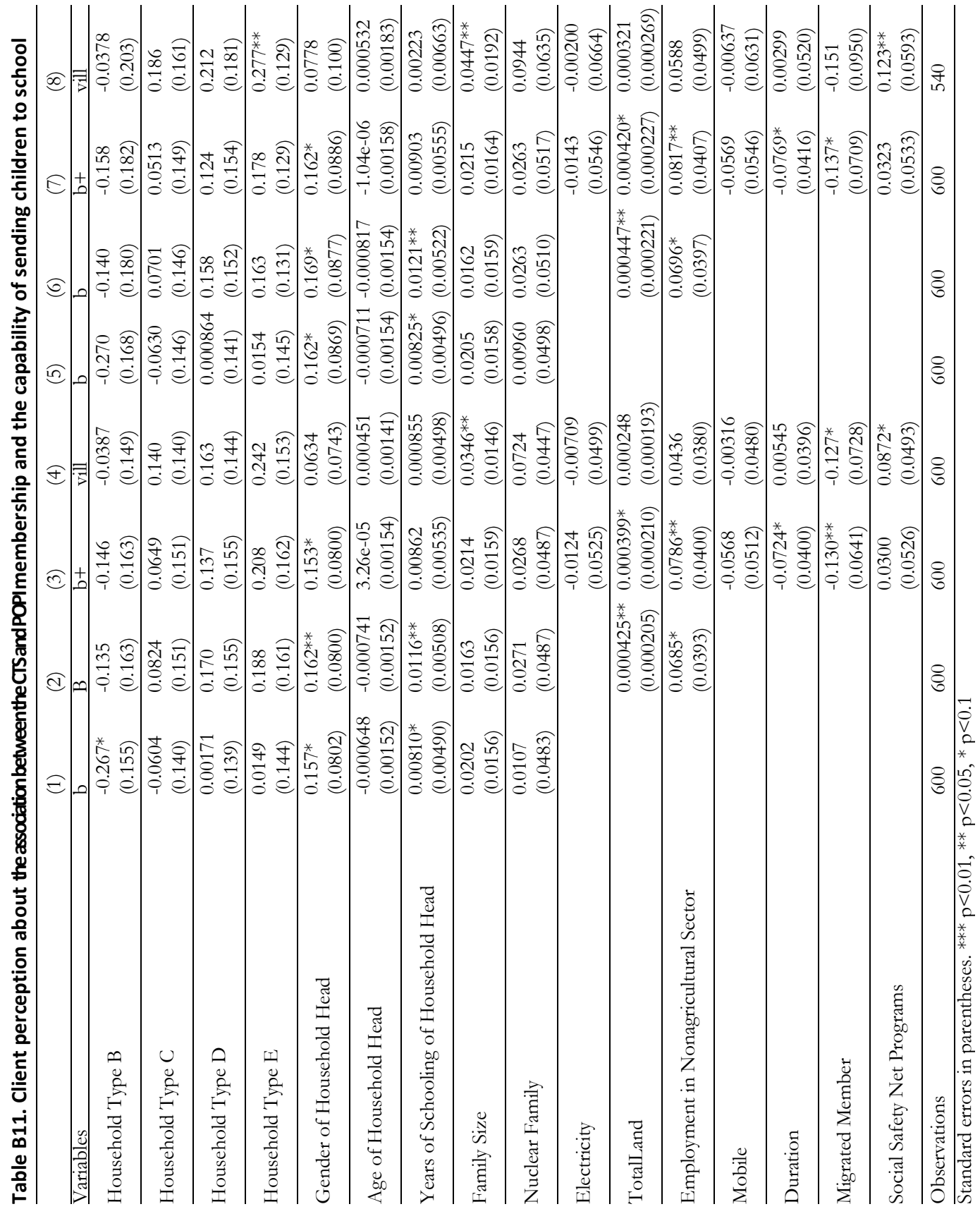


Meherun AHMED, Baqui KHALILY, Abdul KHALEQUE \& Syeda Nafisa NAWAL

\section{Annex C}
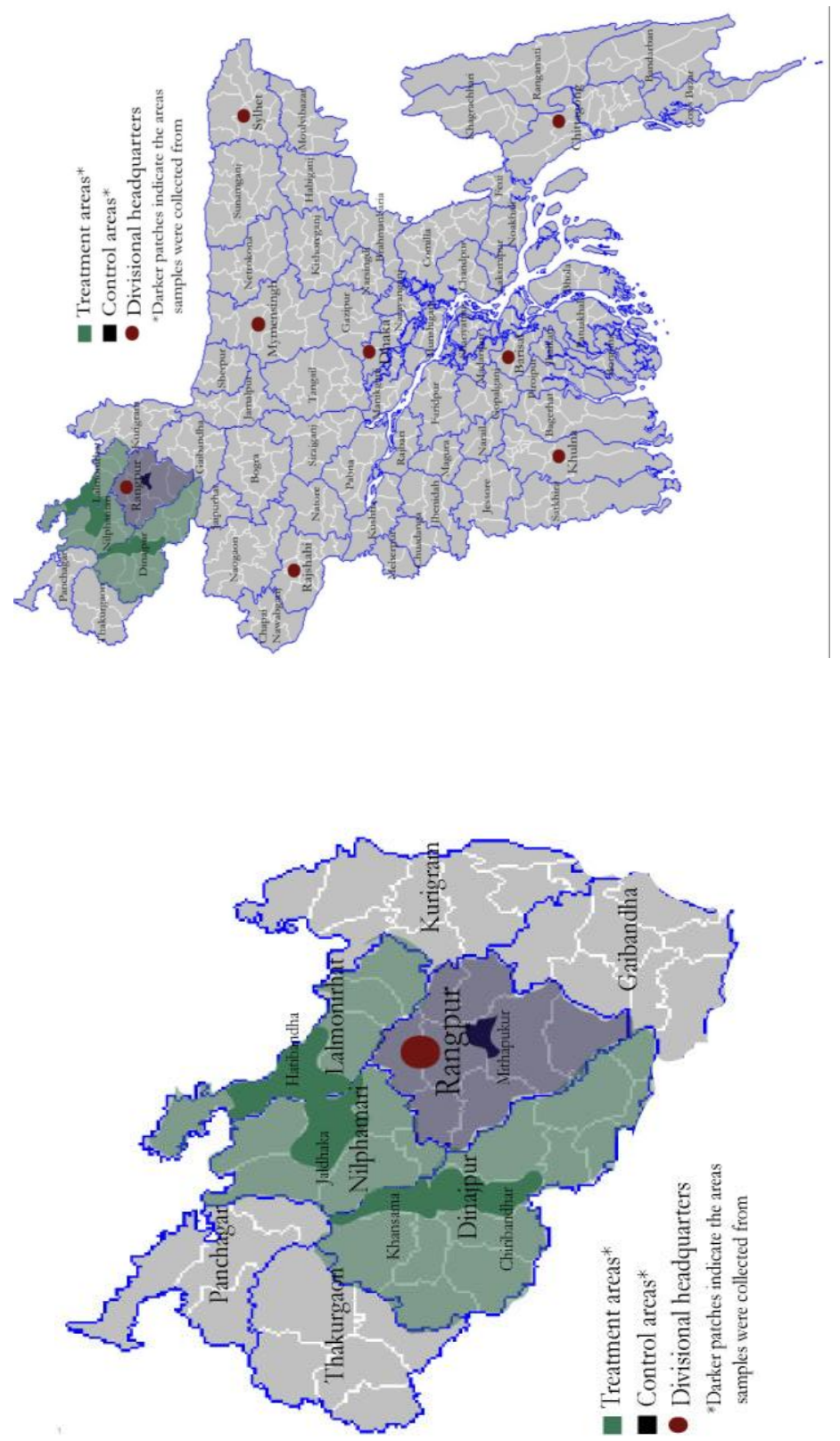